\title{
Tinjauan Model Pembelajaran oleh Orang Tua Pada Masa Pandemi Covid 19 dalam Perspektif Pendidikan Islam
}

\author{
Erliana $^{1^{*}}$ dan Risdoyok ${ }^{2}$ \\ Institute Agama Islam Negeri (IAIN) Bukittinggi*1,2 \\ ${ }^{*}$ email: erlianaputrijambak96066@gmail.com, \\ 2email: risdoyokjournals@gmail.com
}

\begin{abstract}
The dynamics of the learning process felt by parents during home learning, many parents find it difficult to provide guidance, direct or explain materials that their children do not understand. On the other hand, all this time, parents have been comfortable leaving their children in educational institutions, all of them submitting the entirety of their children's education issues to schools. The purpose of this study was to find out and obtain data about the learning model by parents during the COVID-19 pandemic based on an Islamic perspective. This type of research is "library research" by describing the data that has been collected, then selecting and processing the necessary data according to the discussion in the study. The results showed that the habituation model carried out by parents in guiding children during the covid-19 pandemic was (a) making schedules and rules together, (b) activity ideas, (c) Positive communication, (d) reminding time and introspection, (e) reflection and relation.
\end{abstract}

Keywords: Learning Model, Parents, Islamic Education Perspective

Artikel Info

Received:

07 October 2021

Revised:

28 October 2021

Accepted:

20 November 2021

Published:

02 December 2021

\section{Abstrak}

Dinamika proses pembelajaran yang dirasakan oleh orang tua selama pembelajaran dirumahkan, banyak dari orang tua merasa kesulitan dalam memberi bimbingan, mengarahkan maupun menjelaskan materi-materi yang tidak dipahami oleh anaknya. Sisi lain, selama ini orang tua sudah nyaman menitipkan anaknya di lembanga pendidikan semua menyerahkan secara keseluruhan persoalan-persoaln pendidikan anak ke sekolah. Tujuan dari penelitian ini adalah untuk mengetahui dan memperoleh data tentang model pembelajaran oleh orang tua pada masa pandemi covid 19 yang berdasarkan perspektif Islam. Jenis penelitian "library research" dengan mengambarkan terhadap data-data yang telah dikumpulkan, kemudian memilih dan mengolah data yang diperlukan sesuai dengan pembahasan dalam penelitian. Hasil penelitian menunjukkan bahwa model pembiasaan 
INTIQAD: JURNAL AGAMA DAN PENDIDIKAN ISLAM

ISSN 1979-9950 (print) || ISSN 2598-0033 (online), http://jurnal.umsu.ac.id/index.php/intiqad

DOI: $10.30596 /$ intiqad.v13i2.7948

Vol. 13, No. 2 (December 2021)

yang dilakukan oleh orang tua dalam membimbing anak pada masa pandemi covid-19 ini adalah (a) membuat jadwal dan aturan bersama, (b) ide kegiatan, (c) komunikasi Positif, (d) ingatkan waktu dan intropeksi, (e) refleksi dan relasi.

Kata Kunci: $\quad$ Model Pembelajaran, Orang Tua, Perspektif Pendidikan Islam.

\section{A. Pendahuluan}

Setiap orang yang lahir di dunia membutuhkan pendidikan, dan setiap orang sangat membutuhkan seorang guru agar pendidikan yang ditekuninya dapat mengantarkan mereka pada kehidupan yang bahagia di dunia dan di akhirat. Jika kamu ingin bahagia di dunia, kamu harus memiliki ilmu, kamu ingin bahagia dengan ilmu akhirat, dan kamu ingin keduanya dengan ilmu. Untuk memperoleh ilmu ini dengan mencapai jenjang pendidikan sebaiknya diarahkan agar tidak disalahgunakan dan bermanfaat bagi kita di dunia ini dan di masa yang akan datang.Saya seorang guru.

Kedua, pendidikan sebagai suatu sistem memiliki banyak unsur yang saling terkait. Salah satu unsur tersebut adalah kurikulum. Unsur-unsur pendidikan perlu dirumuskan secara konseptual dan konseptual, dimulai dengan dasar-dasar filsafat ilmu yang dapat dihitung dan dikembangkan.

(Nata, 2009)

Undang-Undang Nomor 20 Tahun 2003 tentang Sistem Pendidikan Nasional menyatakan: keterampilan yang dibutuhkan oleh diri sendiri, masyarakat, bangsa, dan bangsa. (Sukardi \& Sugiyanti, 2013)

"Pendidikan nasional adalah perolehan keterampilan yang membantu membentuk kehidupan masyarakat dan pembentukan karakter dan peradaban mereka. Orang yang mandiri menjadi warga negara yang demokratis dan bertanggung jawab". (Sukardi \& Sugiyanti, 2013)

Dari sini kita dapat menyimpulkan bahwa pendidikan itu sendiri memiliki tujuan akhir yang dibutuhkan masyarakat. Negara dan negara. Sesuai dengan firman Allah dalam QS. Al-‘Alaq: 1-5, yaitu:

"Bacalah dengan (menyebut) nama Tuhanmu yang Menciptakan, Dia telah menciptakan manusia dari 
segumpal darah. Bacalah, dan Tuhanmulah yang Maha pemurah, yang mengajar (manusia) dengan perantaran kalam, Dia mengajar kepada manusia apa yang tidak diketahuinya.

Dilihat dari penafsiran ayat di atas, sangat erat kaitannya dengan tujuan pendidikan di atas untuk mengembangkan kemampuan kognitif, sikap dan keterampilan siswa berdasarkan norma dan norma yang berlaku baik norma: agama, adat istiadat, hukum, ilmu pengetahuan dan adat istiadat yang baik. Untuk mencapai tujuan tersebut, kita perlu menanamkan sikap disiplin, tanggung jawab, introspeksi, dan percaya diri. Untuk mencapai tujuan pendidikan diperlukan unsur-unsur yang dapat menunjang tercapainya tujuan tersebut.

Ada tiga unsur utama yang harus disertakan dalam proses pendidikan. Yaitu: 1) Pendidik (orang tua, guru, ustadzah, ulama, wali dan pengawas). 2)

Siswa (anak-anak, Suntory); 3) Pengetahuan atau pesan yang disampaikan (nasihat, topik, pembinaan/ceramah/petunjuk). (Heri Jauhari Muchtar, 2008)

Anak-anak akan menjadi baik ketika mereka dibimbing dan dibimbing pada jalan yang baik. Dan peran utama dalam hal ini adalah guru yang ditiru dan ditiru dan model pembelajaran yang digunakan, yang berasal dari proses pembelajaran yang sedang berlangsung.

Pendidikan pada dasarnya adalah tentang memaksimalkan potensi siswa untuk menjadi siswa yang kompeten, inovatif, mandiri dan mandiri dengan iman pribadi dan takut akan Tuhan. (Hasan, 2018)

Menurut Ahmad D. Marimba, pendidikan Islam adalah pembinaan jasmani dan rohani menurut hukum agama Islam untuk membentuk kepribadian utama menurut standar Islam. Menurut Burlian Somad, pendidikan Islam adalah pendidikan yang bertujuan membentuk individu menjadi makhluk yang berkarakter lebih tinggi sesuai dengan standar Allah SWT, dan isi pendidikannya adalah untuk mencapai tujuan tersebut, yaitu ajaran Allah SWT.

Secara rinci, ia mengemukakan Barrian Somad sebagai berikut: "Pendidikan disebut pendidikan Islam jika memiliki dua ciri: Pendidikan Islam adalah ajaran Allah SWT, yang secara lengkap dirinci dalam Al-Qur'an, dan implementasinya digambarkan oleh 
Nabi Muhammad SAW. Itu dalam praktik kehidupan sehari-hari. (Djamaluddin dan Abdullah, 1996)

Setelah di atas, pendidikan Islam pada hakekatnya menekankan pada tiga hal: 1) upaya pendidikan menggunakan metode-metode tertentu, khususnya metode-metode latihan untuk mencapai pembinaan mental siswa, 2) siswa berupa materi, bahan ajar yang diberikan sudah tersedia. Artinya, berbagai macam ilmu alam dan ilmu manusia yaitu pandangan hidup dan pandangan hidup berdasarkan nilai-nilai etika Islam 3) Tujuan pendidikan yang dicapai adalah untuk membina manusia yang berakal dan berakhlak mulia, serta adil dan makmur Tercapainya kemaslahatan umat dalam masyarakat, ridha Allah SWT. (Moh Roqib, 2009).

Fondasi dan sumber pendidikan Islam adalah hasil Al Quran, Sunnah, sesama bahasa, kesejahteraan sosial, nilai-nilai moral, dan pemikiran dalam Islam (Mukhlish, 2019)

Tujuan pendidikan Islam menitikberatkan pada kemampuan mengimplementasikan nilai-nilai Islam. NS. Mewujudkan pribadi Islam yang dapat tumbuh menjadi hamba Tuhan yang setia, bertaqwa, berilmu, maha kuasa dan bertakwa.

Menurut Al Kabishi, tujuan pendidikan Islam adalah untuk mengembangkan kepribadian anak menurut berbagai nilai-nilai Islam, menumbuhkan rasa cinta agama, mengikuti ajaran agamanya dan berpegang teguh pada nilai-nilai tersebut. Berperilaku agama itu sendiri.

Model pembelajaran adalah kerangka konseptual yang menggambarkan proses sistematis pengorganisasian pengalaman belajar untuk mencapai tujuan pembelajaran yang sangat dinanti. Alternatifnya, model pembelajaran ini merupakan rencana dan pedoman yang sistematis dalam jalannya kegiatan pendidikan dan pembelajaran bagi pendidik, yang pada akhirnya mengarah pada perubahan perilaku. Kemampuan berpikir tidak ada duanya. (Diajukan et al., 2018)

Model pembelajaran adalah rancangan kegiatan pembelajaran agar terlatih dengan baik, menarik, mudah dipahami, dan dalam urutan yang logis. Model pembelajaran berfungsi sebagai panduan untuk merancang dan mengimplementasikan pelajaran. Oleh karena itu, pemilihan model sangat 
tergantung pada jenis materi yang diajarkan kepada siswa, tujuan (kemampuan) yang dicapai dalam belajar, dan tingkat kemampuan siswa. (Ngalimun, 2016)

Dari sini dapat kita simpulkan bahwa penggunaan model dalam pembelajaran, maka pembelajaran lebih terarah, lebih mudah mencapai apa yang diinginkan, dan dapat tercapai sesuai dengan tujuan yang telah ditetapkan. .. Belajar secara umum mengacu pada proses belajar dimana seorang siswa terlibat secara aktif bekerja sama dengan temannya untuk menyelesaikan materi yang diberikan oleh guru. Hal ini sejalan dengan pernyataan Al-Qur'an tentang pentingnya kerjasama dan gotong royong, terutama dalam proses pembelajaran (kebaikan). Allah SWT berfirman hal ini tertuang dalam QS. Al-Maidah: 2.
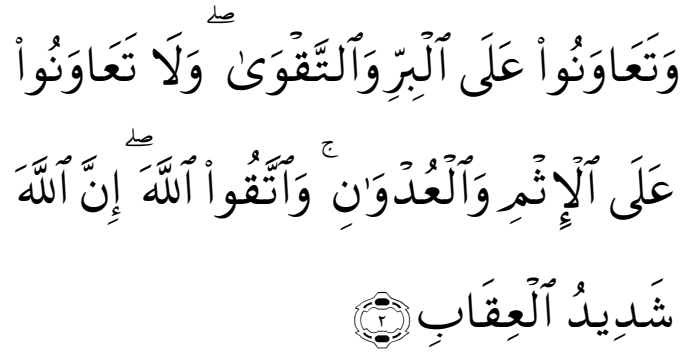

"dan tolong-menolonglah kamu dalam (mengerjakan) kebajikan dan takwa, dan jangan tolongmenolong dalam berbuat dosa dan pelanggaran. dan bertakwalah kamu kepada Allah,
Sesungguhnya Allah Amat berat siksa-Nya." (QS. Al-Maidah: 2)

Syair tersebut menjelaskan bahwa Allah SWT memerintahkan manusia untuk saling tolong-menolong dan gotong royong, terutama dalam kegiatan belajar. Sudah diketahui dengan baik betapa pentingnya sains dalam kehidupan, dan akan sangat bagus jika kita bisa saling membantu untuk tujuan yang sah ini. Salah satu contohnya adalah pembelajaran ini dimana siswa bekerja sama dan saling membantu dalam kegiatan belajarnya.

Model pembelajaran adalah keseluruhan rangkaian penyajian materi yang meliputi seluruh aspek pra dan pasca pembelajaran oleh guru, dan semua fasilitas yang relevan yang digunakan secara langsung maupun tidak langsung dalam proses belajar mengajar. (Istarani, 2014)

Model pembelajaran adalah pola yang menjadi pedoman dalam merencanakan pembelajaran di kelas atau tutorial. Menurut Arends, model pembelajaran berkaitan dengan pendekatan yang digunakan, seperti tujuan pembelajaran, tahapan kegiatan pembelajaran, dan lingkungan belajar. Dan manajemen kelas. Model 
pembelajaran dapat didefinisikan sebagai kerangka konseptual yang menggambarkan pendekatan sistematis untuk mengatur pengalaman belajar untuk mencapai tujuan pembelajaran.

\section{Berkenaan dengan pemikiran} Joyce, fungsi model adalah bahwa melalui model pembelajaran, guru dapat membantu guru memperoleh informasi, gagasan, keterampilan dan gagasan serta mengungkapkan gagasannya. Modal belajar juga berfungsi sebagai pedoman bagi perancang pembelajaran dan guru dalam merencanakan kegiatan pendidikan dan pembelajaran.

Berdasarkan beberapa gambaran di atas, model pembelajaran mengacu pada sintaks pembelajaran dari awal sampai akhir dan menerapkan berbagai jenis kegiatan pendidikan dengan apa yang diharapkan, proses interaksi antara siswa dan guru.Anda dapat menyimpulkan bahwa itu adalah pola desain yang menggambarkan. hasil. Model pembelajaran digunakan sebagai konsep holistik yang mencakup pendekatan, strategi, metode, metode, dan taktik dalam proses pembelajaran. (Isrok'atun, 2018)

Tujuan utama model pembelajaran adalah untuk membantu sains dipahami, dipahami, diingat, dikuasai, serta dipraktikkan, sesuai dengan gaya belajar yang baik berdasarkan keterampilan individu, termasuk kecerdasan majemuk. Dalam kehidupan sehari-hari.

Fenomena pendidikan yang terjadi setiap kali terjadi kemerosotan moral (harm) di masyarakat telah menyebabkan semua pemangku kepentingan, termasuk orang tua, untuk segera beralih ke lembaga pendidikan dan menuduh mereka tidak membesarkan anak dengan baik di tanah air. Klaim tersebut difokuskan pada pendidik (guru) yang dianggap tidak ahli dalam menjaga moralitas bangsa. Klaim langsung ini diarahkan dan dikejar oleh para guru atau pendidik ketika anak-anak negara mengalami korupsi moral dan keterbelakangan teknis. Pendidikan pada dasarnya adalah tugas orang tua dengan melibatkan sekolah dan masyarakat. (Moh Roqib, 2009)

Tugas mendidik anak manusia pada dasarnya ada pada orangtuanya,, namun karena danya beberapa keterbatasan yang dimiliki oleh orang tua dari masingmasing anak didik maka tugas ini kemudian diamanatkan kepada 
pendidik di madrasah (sekolah), masjid, mushallla, dan lembaga pendidikan lainnya (Moh Roqib, 2009)

Dalam konteks yang lebih luas, setiap orang adalah pendidik, sehingga kita perlu menjaga dan meningkatkan kualitas sekaligus menjadi panutan bagi orang lain. Pendidik Islam secara individual bertanggung jawab atas pengembangan mata pelajaran siswa. Karena itu, kelahiran seorang anak dimulai dengan orang tua, dan pekerjaan membesarkannya ada di pundak semua orang tua. Dan karena orang tua paling dekat dengan subjek pendidikan lapangan mereka dan paling tertarik pada anak-anak mereka, mereka menerima pekerjaan dan tanggung jawab membesarkan anak-anak mereka. Anak-anak belajar melalui interaksi dengan lingkungan. Ia dibesarkan oleh lingkungan, terutama lingkungan keluarga dan masyarakat. Oleh karena itu, semua orang tua dan anggota masyarakat adalah pendidik.

Setiap orang tua memiliki peran pendidikan, dan setiap orang tua perlu memperhatikan anaknya, sehingga perlu dilakukan dengan baik. a) Anak sebagai generasi penerus keturunan, b) Anak adalah kebanggaan dan belaian orang tuanya, c) Doa anak yang baik adalah investasi orang tuanya setelah kematian. (Moh Roqib, 2009)

Tugas mendidik orang tua bukan hanya sebagai perintah agama, tetapi mendidik anak memenuhi kebutuhan psikologis (mental) dan kepentingan (diri) mereka sebagai individu dan sebagai anggota masyarakat, karena itu adalah departemen. Namun, tugas parenting terpaksa dilimpahkan kepada seorang pendidik, guru, guru, atau orang lain yang bernama Ustadz karena beberapa alasan: Anak-anak di rumah cenderung kurang fokus, efektif, efisien dan lebih mahal. Pendidikan didelegasikan kepada pihak lain, namun kewajiban dan tanggung jawab orang tua tetap signifikan dan tidak dapat sepenuhnya dilimpahkan kepada pendidik di sekolah dan lembaga lain. (Moh Roqib, 2009)

Orang tua berkewajiban untuk membesarkan anak-anaknya, tetapi orang tua tidak dapat dipisahkan dari keluarga dan komunitas sosialnya. Bagi semua anak, orang tua adalah orang yang paling pantas mendapatkannya. Sejak lahir di Bumi, semua anak telah memainkan peran penting bagi orang tua mereka, termasuk peran pendidikan 
mereka. Orang tua begitu banyak dan berharga sehingga dalam Islam orang tua ditempatkan dengan sangat baik di depan anak-anaknya. Ayah dan ibu berhak untuk dihormati oleh anakanaknya, terutama ibu yang telah mendedikasikan segalanya untuk anakanaknya, dan ibu diberikan tiga kali status bergengsi ayah mereka. Kasih sayang dan kesabaran orang tua sangat penting bagi perkembangan fisik dan mental siswa, terutama dalam keluarga.

Sekali lagi, mengasuh anak adalah kewajiban semua orang tua. Dari perspektif ajaran Islam, membesarkan anak adalah tugas orang tua untuk mempersiapkan masa depan yang cerah dan berhenti mengkhawatirkan masa depan mereka, yaitu masa depan yang baik, sehat dengan aspek spiritual yang tinggi. Semua prestasi tersebut tidak dapat diraih oleh orang tua tanpa pendidikan yang baik bagi anakanaknya.

Melibatkan orang tua dalam membesarkan anak-anak mereka adalah panduan sosial dan psikologis. Karena pada umumnya setiap individu ingin menduduki posisi yang baik di hadapan orang lain, dan setiap individu percaya bahwa kehormatan adalah kebutuhan naluri kemanusiaannya. Kewajiban membesarkan anak bagi orang tua dilaksanakan oleh semua orang tua yang mengharuskan mereka bekerja dengan berbagai organisasi, terutama lembaga pendidikan dan kelompok sosialnya, dan dengan masyarakat sekitar untuk membesarkan anak-anaknya dengan baik. Oleh karena itu, tanggung jawab terbesar untuk membesarkan anak terletak di pundak orang tua. Kedepannya anak akan mampu melahirkan generasi yang lebih berkualitas dan mandiri, sehingga tidak lepas dari tanggung jawabnya.

Orang tua mendelegasikan pendidikan anak mereka ke sekolah dan lembaga pendidikan lokal lainnya seperti masjid dan mushola. Kepercayaan orang tua terhadap pendidik sekolah, TPQ, madrasah, dan perguruan tinggi adalah proses pendidikan anak sedangkan pendidik bertindak atas nama orang tua siswa dan anak berada di lembaga tersebut. Setelah anak-anak kembali ke rumah mereka, pekerjaan dan kewajiban membesarkan mereka tentu saja berada di tangan orang tua mereka. Hal ini karena, kecuali pondok pesantren yang santrinya ditempatkan di pondok 
pesantren, lama kelamaan anak-anak tinggal lebih lama di rumah daripada di sekolah, dan kewajibannya mendidik melalui pendidik lebih lama dari pada orang tuanya. Tentunya model pendidikan Pesantren ini kedepannya akan semakin menarik untuk diperhatikan dan dikembangkan lebih lanjut dalam proses pendidikannya. (Moh Roqib, 2009)

Pada saat sekarang ini orang tua diberi tanggung jawab lebih oleh pemerintah untuk mendidik anakanaknya dirumah walaupun pada hakikatnya, kewajiban untuk mendidik anak itu adalah orang tua, namun untuk lebih terrahnya potensi dan bakat anakanaknya ada sekolah atau lembaga pendidikan untuk menuntut ilmu. Namun karena wabah penyaklit yang mematikan yaitu virus Corona (Covid 19).

Pada masa pandemi covid 19 ini, dalam dunia pendidikan yang menerapkan model pembejaran bukan lagi guru tapi, tanggung jawab dan tugas guru diberikan kepada orang tua, yang menjadi model dalam pembelajaran adalah orang tua. Karena pada saat ini yang lebih dominan dalam pendidikan adalah orang tua.
Pada saat ini orang tua menjadi pelopor pendidikan yang sangat perperan penting pada saat ini. Tanpa ada bimbingan dari orang tua saat ini, maka pendidik saat tidak akan berhasil. Keteladanan yang diberikan oleh orang tua terhadap pendidikan anak, saat berarti. Jika model pembiasaan dan keteladanan hanya dibatasi pada guru saja, maka, hal tersebut tidak akan di di peroleh oleh peserta didik saat ini.

Mengenai masalah di sini, saat ini banyak sekali jenis model pembelajaran yang cukup sulit diperoleh siswa dari guru. Karena tugas mendidik saat ini sudah dialihkan kepada kedua orangtua kembali dirumah, kebanyakkan dari orang tua saat ini tidak mampu memberikan keteladanan dan pembiasaan kepada anak-anaknya, karena pada awalnya mereka sudah mempercayakan guru untuk mendidik anak-anaknya di sekolah di karenakan, karena mereka sibuk bekerja.

Namun permasalahannya pada saat ini dunia sedang dilanda oleh wabah penyakit yang mematikan yang disebut virus Corona (Covid 19). Yang mana virus ini bisa menyebar ditempattempat yng banyak perkumpulanperkumpulan, termasuk lembaga 
pendidikan,yang mana lembaga

pendidikan merupakan tempat

berkumpulnya orang-orang dalam menuntut ilmu.

Jadi karena pandemi covid 19 ini sudah menyebar kepenjuru dunia, di akibatnya semua lembaga/fasilitas pendidikan ditutup untuk sementara. Dan proses belajar dan mengaajar dilakukan mlalui daring dan lain-lain. Anak anak tetap belajar, tetapi dirumah dan tidak dibenarkan disekolah untuk kumpul-kumpul diruangan lokal, jadi otomatis semua proses pendidikan baik itu bimbingan, pengarahan, diilakukan oleh orang tua, sedangkan guru hanya memantau dari jauh dan memasukkan gaji pekerja.

Pada masa pandemi covid 19 ini banyak orang tua yang mengeluh, karena mereka tidak mampu menjadi guru dan memberikan keteladaan dan pembiasaan yang baik untuk anakanakya di rumah, karena tidak semua orang tua yang menempuh jenjang pendidikan, banyak terdengar diluaran sana, banyak orang tua yang yang mengeluh. Karena tidak sanggup membimbing anaknya untuk belajar di rumah.
Berdasarkan fenomena di atas penulis tertarik untuk melakukan penelitian tentang Tinjauan Model Pembelajaran oleh Orang Tua Pada Masa Pandemi Covid 19 Dalam Perspektif Pendidikan Islam.

\section{B. Metode Penelitian}

Jenis penelitian ini merupakan penelitian studi Pustaka atau Library Research penelitian pustakan atau Library Research adalah menjadikan bahan yang adadi pustaka berupa bukubuku, majalah ilmiah, dokumendokumen, dan materi lainnya yang dapat dijadikan sumber rujukkan dalam penelitian ini.(Sutrisno Hadi, 2004)

Pendekatan kualitatif adalah suatu pendekatan yang menggunakan dokumen-dokumen manuskrip pemikiran-pemikiran yang ada, dari data yang telah ada, kemudian dikategorikan berdasarkan relevansinya dengan pokok permasalahan yang dikaji.

Sumber data penulis dapatkan pertama Sumber primer dalam penelitian ini adalah sumber asli baik berbentuk dokumen maupun peninggalan lainnya. Data yang penulis peroleh secara langsung dari objek 
penelitian yaitu Model Pembelajaran yang dugunakan oleh orang tua selama pembelajaran daring perspektif pendidikan islam. Adapun sumber primernya yakni buku-buku Model pembelajaran yang ada. Buku primernya adalah buku: Moh Roqib, Ilmu Pendidikan Islam. Sedangkan sumber sekunder merupakan hasil penggunaan sumber-sumber lain yang tidak langsung dan berbagai dokumen yang murni ditinjau dari kebutuhan. Adapun sumber data sekunder yakni buku-buku, internet, maupun sumber yang dubtuhkan dalam penelitian ini.

Pengumpulan data dalam penelitian ini mengunakan metode dokumentasi dengan cara mencari data mengenai variabel yang berupa catatan, transkrip, buku, surat kabar, majalah, prasasti, notulen rapat, legger, agenda dan sebagainya.(Suharsimi Arikunto, 1998)

Metode ini dilakukan dengan cara mencari dan menghimpun bahan-bahan pustaka untuk ditelaah isi tulisan terkait dengan tinjauan model pembelajaran oleh orang tua pada masa pandemi covid 19 pada perspektif pendidikan islam.
Analisis data merupakan penguraian dari bahan yang terkumpul pada untuk menarik kesimpulan. Kali ini metode yang digunakan berupa kualitatif dengan menggunakan analisis isi (content analysis). Dengan harapan mengetahui prinsip-prinsip dari suatu konsep untuk keperluan mengambarkan secara objektif-sistematis tentang suatu teks.(Neong Muhadjir, 1996)

Dalam penelitian ini, penulis menggunakan kolom berpikir induktif. Berpikir induktif adalah seperangkat pemikiran yang dapat digunakan untuk menganalisis masalah atau fenomena tertentu untuk membuat keputusan umum. (Saefuddin Azwar, 1998).

\section{Hasil dan Pembahasan}

Penerapan yang dilakukan oleh orangtua membimbing anaknya belajar dirumah pada masa pandemi covid 19 adalah orangtua di rumah bukan untuk menggantikan semua peran guru di sekolah. Berikut merupakan penerapan pembiasaan oleh orang tua pada masa pandemi covid 19. (1) Buat jadwal dan aturan bersama. Ingatkan anak-anak bahwa aturan dan jadwal yang ditetapkan bersama adalah tanggung jawab setiap anak dan bahwa mereka 
berbagi tanggung jawab untuk mengikutinya. Membantu anak-anak merencanakan kegiatan mereka bukan tentang membuat jadwal mereka sendiri, tetapi tentang membiarkan mereka membuat jadwal mereka sendiri. Ini membantu anak mengambil tanggung jawab untuk semua kegiatan yang direncanakan dilakukan.

Diskusikan atau berikan anak Anda dua pilihan aktivitas sehingga mereka dapat memilih aktivitas apa yang akan dilakukan. (2) Ide kegiatan. Jika Anda bingung tentang apa yang harus mereka lakukan, bantu anak Anda dengan ideide untuk kegiatan. Jika anak Anda kesulitan menemukan ide untuk suatu kegiatan, bantu mereka dengan beberapa hal yang dapat mereka lakukan selain belajar. (3) Komunikasi positif. Bangun hubungan yang positif dan selalu mintalah yang positif, terutama saat anak Anda baru memulai. Tanyakan kepada anak Anda: Apa yang dapat Anda lakukan untuk membantu? Bantu anak Anda memahami apa yang harus dilakukan. Jika masalah berlanjut, orang tua atau anak dapat menghubungi guru lagi melalui telepon, SMS, atau WA untuk penjelasan tugas yang dimaksud. (4) Ingatkan waktu dan
Introspeksi; Ingatkanlah jadwal kegiatan dan waktu yang akan, sedang, dan telah digunakan anak. Mengingatkan kegiatan yang sudah direncanakan bisa membantu mereka mencapai target. Introspeksi atau ingatkan diri kita masingmasing, orangtua bukan orang yang serba tahu segalanya. (5) Refleksi dan Relasi; Orangtua bisa melakukan refleksi tentang apa yang sudah dilakukan bersama secara informal dengan mengobrol atau sambil makan malam atau cara lainnya.

"Ada lima hal penting yang harus dilakukan untuk membangun hubungan positif untuk membantu anak-anak belajar dari rumah. Ini adalah ketika Anda ingin tahu tentang menetapkan dan menerapkan aturan umum dan aktivitas anak Anda. Ini melibatkan mengajukan pertanyaan positif dan menilai semua hal baik yang dilakukan anak-anak. telah dilakukan," tambahnya. (Yulianingsih et al., 2020)

Keakraban merupakan ketentuan syariat Islam bahwa seorang anak diciptakan sejak lahir dalam fitrah yang murni agama dan keimanan kepada Allah SWT, serta dalam fitrah yang murni tauhid. Sebagaimana firman dari 
Allah Swt, dalam QS. Ar-Rum: 30, yaitu:

"Maka hadapkanlah wajahmu dengan Lurus kepada agama Allah; (tetaplah atas) fitrah Allah yang telah menciptakan manusia menurut fitrah itu. tidak ada peubahan pada fitrah Allah. (Itulah) agama yang lurus; tetapi kebanyakan manusia tidak mengetahui" (QS. Ar-Rum: 30).

Sifat Tuhan: Artinya ciptaan Tuhan. Manusia diciptakan oleh Tuhan untuk memiliki naluri religius, agama monoteistik. Jika ada orang yang tidak memiliki tauhid, itu tidak wajar. Tidak ada tauhid hanya karena pengaruh lingkungan.

Dari sini, pembiasaan, bimbingan, dan pengasuhan tampaknya berperan dalam tumbuh kembang anak agar dapat membesarkan mereka dengan tauhid yang murni dan kepribadian yang luhur. Keutamaan jiwa dan etika Islam yang benar. (Abdullah Nasih Ulwan, 2013)

Membiasakan menjadi orang tua sangatlah penting, terutama dalam pendidikan pribadi dan moral. Pembiasaan beragama memasukkan unsur positif ke dalam tumbuh kembang anak. Semakin banyak pengalaman religius yang dimiliki seorang anak melalui pembiasaan, semakin banyak unsur agama yang ada dalam karakternya dan semakin mudah baginya untuk memahami ajaran agama. (Zakiah Derajat, 1993) Membiasakan diri adalah proses pendidikan. Setelah Anda terbiasa, itu menjadi kebiasaan, kecanduan, dan tradisi yang tak tertahankan bagi mereka yang mempraktikkannya. Inilah pentingnya membiasakan diri dalam proses pendidikan. (A. Qodri Azizy, 2002)

Keakraban berasal dari kata
"umum" dengan akhiran peen yang
menunjukkan pentingnya proses. (M. B. Ali dan T. Deli, 1997) Keakraban juga didefinisikan sebagai kinerja jangka panjang yang berkelanjutan dan konsisten dari tindakan atau keterampilan tertentu, yang menjadi kenyataan dan pada akhirnya menjadi kebiasaan yang sulit untuk ditinggalkan. Dalam psikologi, proses pembiasaan disebut "pengkondisian". Proses ini mengungkapkan kebiasaan dan keterampilan, dan akhirnya menjadi kebiasaan pribadi yang diringankan oleh aktivitas sehari-hari. (Hanna Djumhana, 2001)

Semua orang tua Muslim berkewajiban untuk membesarkan anakanak mereka dengan cara yang saleh 
dan patuh terhadap orang tua dan agama mereka. Dalam membesarkan anakanak tersebut, proses yang berlangsung tidak lepas dari dua faktor, internal dan eksternal. Hal ini juga terkait dengan teori perkembangan siswa yang dikenal dengan teori konvergensi. Teori konvergensi menyatakan bahwa seseorang dapat dibentuk oleh lingkungannya dan dengan mengembangkan kemungkinankemungkinan dasar dalam dirinya.

Kemungkinan- kemungkinan dasar yang ada pada diri seorang anak dapat dijelaskan sebagai kemungkinankemungkinan alamiah atau bawaan yang dibawa anak setelah lahir. Karena itu, Anda harus selalu menyesuaikan kemungkinan dasar Anda sehingga Anda dapat mencapai tujuan pengasuhan Anda dengan benar. Pembinaan orang tua kepada anak di lingkungan rumah sebagai faktor eksternal salah satunya dapat dilakukan melalui metode pembiasaan yaitu berupa pemberian kebiasaan yang baik kepada anak. (Armai Arief, 2002)

Keakraban merupakan metode
pendidikan $\begin{aligned} & \text { berupa } \\ & \text { "proses }\end{aligned}$
pembiasaan". (Hery Noer Aly, 1999)
Kebiasaan itu sendiri, di sisi lain, berarti

"perilaku permanen, seragam, dan hampir otomatis (hampir tidak diperhatikan oleh praktisi)."

Menurut Muhammad Zein, orang tua berperan sebagai pengelola dan pendidik keluarga. Menurutnya, ada tiga metode yang digunakan untuk mengasuh anak: "meniru, menghafal, dan membiasakan diri." (Muhammad Zein, 1995) Pembiasaan adalah proses mendidik anak agar terbiasa dengan segala sesuatu dan menjadi kebiasaan. Menurutnya, "kebiasaan ini membawa kecerahan dan cahaya." (Armai Arief, 2002)

Pembiasaan ini merupakan proses selangkah demi selangkah dari pendidikan manusia, menjadikan pembiasaan sebagai teknik pendidikan yang dicapai dengan pembiasaan seharihari yang berkualitas, membiarkan jiwa dibiasakan tanpa menjadi terlalu keras. Tanpa kehilangan banyak energi dan menemukan banyak kesulitan.

Membiasakan diri juga sangat penting, terutama bagi anak-anak. Mereka tidak mengerti apa yang disebut baik dan jahat dalam pengertian moral. Demikian pula, mereka tidak memiliki kewajiban untuk dipenuhi sebagai orang dewasa. Di sisi lain, ada beberapa 
kelemahan yang saya belum memiliki ingatan yang kuat. Sangat mudah untuk melupakan apa yang terjadi dan apa yang terjadi. Di sisi lain, perhatian mereka langsung tertuju pada hal-hal baru dan favorit.

Oleh karena itu, dalam hal ini, mereka perlu memperkenalkan tindakan, keterampilan, kemampuan, dan gagasan tertentu. Anak-anak perlu dibiasakan bermain, berbicara, belajar, bekerja, dll, serta mandi, makan dan tidur secara teratur. Pembiasaan adalah kegiatan berkelanjutan yang ada dalam kehidupan sehari-hari anak untuk menjadi kebiasaan yang baik.

Perkembangan familiar meliputi aspek nilai moral dan agama, perkembangan sosial, emosional dan kemandirian. Dari segi pembinaan moral dan nilai-nilai agama, diharapkan anak semakin meningkatkan pengabdiannya kepada Tuhan Yang Maha Esa dan meningkatkan sikapnya untuk meletakkan dasar kewarganegaraan yang baik. Aspek perkembangan sosial, emosional, dan kemandirian perlu memfasilitasi pengendalian emosi, interaksi yang baik dengan orang lain dan orang dewasa, serta kemampuan menolong diri sendiri dalam kerangka kecakapan hidup. (Mudjito, 2007)

Pertumbuhan intelektual anakanak prasekolah tidak memungkinkan mereka untuk berpikir logis dan memahami abstrak. Maka apa yang Anda katakan kepadanya dapat diterima. Mereka tidak bisa menjelaskan apa yang salah dan apa yang baik. Hukum dan peraturan agama belum dipahami dan dipertimbangkan oleh diri kita sendiri. Dia menerima semua yang dijelaskan kepadanya. Apa yang menunjukkan nilai agama dan moral kepada anak-anak masih kabur dan tidak dipahami. (Zakiah Darajat, 2005)

Mendidik anak pada sifat-sifat yang terpuji tidak hanya membutuhkan penjelasan pengertian, tetapi juga membiasakan perbuatan baik yang diharapkan kelak memiliki sifat baik dan menjauhi sifat-sifat yang memalukan. Berikut ini juga berlaku untuk pendidikan agama. Semakin muda usia anak, semakin banyak pendidikan agama dan pembiasaan yang perlu dimiliki anak. Dan semakin tua anak, semakin Islam seharusnya menggunakan pembiasaan sebagai metode pendidikan. 
Islam mengubah semua sifat baik menjadi kebiasaan, memungkinkan jiwa untuk melaksanakan kebiasaan ini tanpa banyak usaha atau usaha, tanpa kehilangan banyak energi atau menemukan banyak kesulitan. Oleh karena itu, pembiasaan merupakan salah satu pilar terpenting pendidikan dan kelembagaan, dan cara yang paling efektif untuk membangun iman dan meningkatkan moral pada anak. (Abdullah Nasih Ulwan, 2013)

Keakraban adalah proses membentuk kebiasaan baru dan memperbaiki kebiasaan yang sudah ada. Keakraban menggunakan perintah, panutan, pengalaman khusus, serta hukuman dan penghargaan. Tujuannya adalah untuk mengembangkan sikap dan kebiasaan baru yang lebih tepat dan positif dalam arti siswa (secara kontekstual) selaras dengan kebutuhan ruang dan waktu mereka. Apalagi makna yang benar dan positif itu sesuai dengan norma dan nilai moral umum baik agama, adat maupun budaya. (Muhibbin Syah, 2000)

Dari penjelasan di atas, tujuan memelihara keakraban di sekolah adalah untuk secara konsisten dan terus menerus memahami tujuan siswa sehingga benar-benar tertanam dalam diri anak dan akhirnya menjadi kebiasaan yang sulit untuk dikuasai. . masa depan.

Pengembangan agama melalui adat dapat dilakukan dalam beberapa bentuk, antara lain: (a) Membiasakan akhlak dengan membiasakan berperilaku baik baik di dalam maupun di luar sekolah, seperti berbicara yang sopan, berpakaian yang sopan, dan menghormati orang yang lebih tua. (b) Membiasakan beribadah, membiasakan sholat berjamaah di mushola sekolah, mengucapkan salam saat masuk kelas, dan membacakan "Bass Miller" dan "Handara" di awal dan akhir pelajaran. (c) Dengan membiasakan iman, membuat anak-anak memperhatikan dan berpikir tentang alam semesta, dan dengan bergerak secara alami dari dunia ke alam gaib dalam bentuk pembiasaan yang benar-benar dan tulus diyakini oleh anak-anak. Dan merenungkan penciptaan alam semesta. (Ramayulis, 1994)

Pembentukan

kebiasaankebiasaan ini dibentuk oleh pengulangan dan mengambil bentuk yang langgeng dengan kepuasan. Membiasakan diri itu sulit dan bisa 
memakan waktu. Kesulitannya adalah pada awalnya Anda tidak tahu apa yang akan dibiasakan oleh seseorang atau anak, jadi membiasakan yang baik harus terjadi sesegera mungkin sehingga yang baik menjadi kebiasaan ketika Anda dewasa.

Ada beberapa syarat yang harus diperhatikan agar anak terbiasa. (a) Mulailah kebiasaan sebelum terlambat, yaitu sebelum anak Anda memiliki kebiasaan lain yang bertentangan dengan kebiasaan normal. (b) Kebiasaan itu harus dilakukan secara terus menerus (berulang-ulang) secara teratur sehingga pada akhirnya akan menjadi kebiasaan uang otomatis. (c) Pendidikan harus konsisten, kokoh dan kokoh dalam sikap yang dianut. Jangan beri anak kesempatan untuk mematahkan kebiasaan yang sudah mapan. Awalnya, kebiasaan mekanis harus menjadi kebiasaan yang menyertai hati nurani Anda.

Pendidikan Keluarga berfokus pada untuk mengajarkan lebih dari nilai-nilai moral agama anak-anak dengan memperkenalkan simbol-simbol agama, tata cara sholat, membaca Alquran, dan doa. Orang tua diharapkan membiasakan diri untuk berdoa, membaca Al-Qur'an, dan membaca Doa Adho setiap kali mereka melakukan sesuatu atau aktivitas baru. Keakraban adalah aspek praktis dari pelatihan dan persiapan. Usia anak-anak lebih mudah untuk diterima, diajarkan dan dibiasakan dibandingkan kelompok usia dan tahapan lainnya. Oleh karena itu, orang tua dan guru perlu fokus mengajarkan kebaikan dan pembiasaan kepada anak-anaknya saat mereka mulai berpikir dan memahami esensi kehidupan.

Keakraban pada dasarnya adalah tentang pengalaman. Membiasakan itu dipraktikkan. Oleh karena itu, inti dari keakraban adalah pengulangan. Keakraban sangat efektif dalam mengembangkan sikap karena mengajarkan anak kebiasaan yang baik sejak dini. Sifat anak usia dini adalah meniru apa yang dilakukan orang-orang di sekitarnya, baik dari ayah maupun ibunya, serta kerabat terdekatnya.

Oleh karena itu, jika orang tua ingin anaknya tumbuh dengan kebiasaan dan akhlak yang baik yang patut dipuji, mereka harus menjadi yang terbaik di mata mereka. Ke anak adalah dasar dari orang tua. Pikirannya murni seperti mutiara murni senilai tinggi. 
Ketika dia terbiasa dengan kebaikan dan pengalamannya, dia akan tumbuh dan bahagia di dunia dan di akhirat. (Abdullah Nasih Ulwan, 2013)

Setiap anak membutuhkan latihan-latihan dan pembiasan untuk menjalankan sebuah aturan, untuk itu orangtua perlu melatih dan membiasakan anak agar tunduk dan patuh dalam menjalankan sebuah nilainilai, baik itu yang bersifat individual ataupun sosial. Kita tahu bahwasanya semenjak dilahirkan setiap anak memiliki kesanggupan untuk dapat terealisasikan (terwujud) sejalan dengan adanyalatihan-latihan, dimana masingmasing anak memiliki kematangan yang berbeda-beda dalam mewujudkannya.

Demikian pula dalam pendidikan anak membutuhkan latihan dan pembiasaan, sehingga mereka dapat menumbuhkan dan mengembangkan potensi-potensi yang ada dalam diri mereka secara optimal. Dan pada akhirnya mereka akan menjadi pribadipribadi yang mandiri dan mantap.

Dalam sebuah Hadist Nabi menjelaskan bahwa Rasulullah Saw bersabda:

"suruhlah anak-anakmu
melaksanakan shalat ibadah
shalatjika merekatelah berusia 7

tahun, apabila telah berusia 10 tahun maka pukullah ia (jika tidakmau melakukan shalat)dan pisahkanlah tempat tidurnya".

Kenapa nabi Muhammad Saw menganjurkan kepada setiap orang tua agar menyuruh anak-anaknya untuk menjalankan ibadah shalat ketika mereka telah berusia 7 tahun, adalah tidak lain supaya mereka terbiasa dengan hal itu, sehingga manakala mereka telah menginjak usia balig sholat telah menjadi bagian dari rutinitas yang sulit untuk ditinggalkan, sebab shalat telah menjadi ruh dan bagian dari jiwa mereka.

Untuk membina anak agar mempunyai sifat-sifat terpuji, seperti berkata jujur, sopan terhadap yang lebih tua dan sebagainya. Sesungguhnya tidaklah cukup dengan penjelasan dan pengertian saja, akan tetapi perlu adanya latihan-latihan dan pembiasaan, sebab pertumbuhan kecerdasan pada anak-anak yangmasih berusia sekolah dasar belum dapat memahami hal-hal yang abstrak dan berfikir logis. Sehingga nilai-nilai agama atau pun moral yang diberikan oleh orang tua kepada mereka masih sangat kabur dan sulit untuk difahami. Maka disinilah manfaat daripada latihan-latihan dan 
pembiasaan dengan disertai adanya

keteladanan dari orang tua tentunya.

Oleh karena itu, diharapkan semakin cepat orang tua dibiasakan dengan nilai-nilai agama maka semakin tua pula usianya. Bagaimanapun, apa yang diajarkan kepada anak-anak melalui pelatihan dan pembiasaan harus menjadi bagian dari kepribadian mereka secara keseluruhan dan kuat. (Labib, 2007)

Model pembiasaan ini mendorong dan memberikan ruang kepada anak didik pada teori-teori yang membutuhkan aplikasi langsung, sehingga teori yang berat menjadi ringan bagi anak didik bilasering dilaksankan. Model pembiasaan di dalam Al-Qur'an terdapat dalam QS.

\section{Al-Baqarah: 25.}

"dan sampaikanlah berita gembira kepada mereka yang beriman dan berbuat baik, bahwa bagi mereka disediakan surgasurga yang mengalir sungaisungai di dalamnya. Setiap mereka diberi rezki buah-buahan dalam surga-surga itu, mereka mengatakan: "Inilah yang pernah diberikan kepada Kami dahulu." mereka diberi buah-buahan yang serupa dan untuk mereka di dalamnya ada isteri-isteri yang suci dan mereka kekal di dalamnya” (QS. Al-Baqarah: 25).
Model pembiasaan yang diberikan orang tua kepada anaknya sangat berarti pada perkembangan dan pendidikan anaknya. Bagi orang tua anak adalah dambaan, buah hati, pelipur lara, amanah, sekali gus cobaan yang diberikan oleh Allah. oleh karena itulah orang tua harus mengetahui dan memahami dengan benar apakah fungsi dari anak, dalam sebuah keluarga dan bagaimanakah model dalam pendidikan anak yang harus mereka terapkan sehingga pendidikan dari keluarga tersebutlah diharapkan akan tercetak generasi-generasi umat yang tangguh di dalam muapun di luar.

Ibu adalah madrasah pertama bagi anak-anaknya, ibulah yang lebih banyak berinteraksi dan berhubungan dengan anak-anaknya ketimbang dengan ayahnya, dari mulai ia tinggal di dalamrahim si ibu hingga ia tumbuh menjadi dewasa. Karena itu pula setiap perilaku ibu menjadi teladan (Qudwah) dan pelatihan yang sangat penting bagi anak-anaknya. Jika dalam keseharian seorang ibu mencerminkan sikap yang penuh ketaatan dan konsisten dalam menunaikan kewajiban, maka sungguh ia telah mengalirkan ruh religi dan keimanan dalam jiwa anaknya. Namun 
jika sebaliknya seorang ibu senantiasa menunjukkan kemaksiatan, sikap kasar dan berperanggai buruk, yang pada akhirnya membvuat sang anak memiliki kecenderungan untuk berbuat hal-hal yang negatif.

Oleh karena itu, pendidikan dan pengasuhan keluarga merupakan kebutuhan yang sangat mendasar dan sangat penting, dimana ibu dan ayah berperan penting dalam role model yang diberikan orang tua kepada anakanaknya. (Labib, 2007)

\section{Simpulan}

Hal itu berdasarkan survei literatur penulis terhadap review model pembelajaran oleh orang tua selama pandemi Covid-19 dari perspektif pendidikan Islam. Berikut rangkuman model pembelajaran yang diterapkan orang tua selama pandemi COVID-19. Permulaan; Keakraban adalah bagian praktis dari pelatihan dan persiapan. Usia anak-anak lebih mudah untuk diterima, diajarkan dan dibiasakan dibandingkan kelompok usia dan tahapan lainnya. Oleh karena itu, orang tua dan guru perlu fokus mengajarkan kebaikan dan pembiasaan kepada anak- anaknya saat mereka mulai berpikir dan memahami esensi kehidupan.

Model pembiasaan yang digunakan orang tua untuk membimbing anaknya selama masa pandemi Covid19 adalah (a) menetapkan jadwal dan aturan bersama, (b) ide kegiatan, (c) komunikasi aktif, (d) introspeksi waktu dan ingat, (e) Hubungan dengan cerminan.

\section{E. Daftar Pustaka}

A. Qodri Azizy. (2002). Pendidikan Untuk Membangun Etika Sosial. Aneka Ilmu.

Abdullah Nasih Ulwan. (2013). Tabiyatul Aula Pendidikan Anak Dalam Islam. Khatulistiwa Pers.

Armai Arief. (2002). Pengantar Ilmu dan Metodoligi Pendidikan Islam. Ciputat Pers.

Diajukan, S., Sarjana, G., Tarbiyah, I., \& Oleh, K. (2018). Kerjasama Guru dan Orang Tua Dalam Meningkatkan Hasil Belajar Siswa UNIVERSITAS ISLAM NEGERI Kerjasama Guru dan Orang Tua Dalam Meningkatkan Hasil Belajar Siswa.

Djamaluddin dan Abdullah. (1996). Kapita Salekta Pendidikan Islam. CV Pustaka Setia.

Hanna Djumhana. (2001). Integrasi 
ISSN 1979-9950 (print) || ISSN 2598-0033 (online), http://jurnal.umsu.ac.id/index.php/intiqad

DOI: 10.30596/intiqad.v13i2.7948

Vol. 13, No. 2 (December 2021)

Psikologi dengan Islam Menuju Psikologi Islami. Yayasan Insan Kamil dan Pustaka Pelajar.

Hasan, N. (2018). Pola Kerjasama Sekolah dan Keluarga dalam Pembinaan Akhlak (Studi Multi Kasus di MI Sunan Giri Dan MI Al-Fattah Malang). Al-Makrifat: Jurnal Kajian Islam, 3(01), 97111.

http://ejournal.kopertais4.or.id/tapa lkuda/index.php/makrifat/article/vi ew/3136

Heri Jauhari Muchtar. (2008). Fiqih Pendidikan. PT remaja Rosda Karya.

Hery Noer Aly. (1999). Ilmu Pendidikan Islam. Logos Wacana Ilmu.

Isrok'atun. (2018). Model-Model Pembelajaran Matematika. PT Bumi Aksara.

Istarani. (2014). $58 \quad$ Model Pembelajaran Inovatif. Media Persada.

Labib. (2007). Rumah Tanggaku Bagaikan Sorga Bagiku. Putra Jaya.

M. B. Ali dan T. Deli. (1997). Kamus Lengkap Bahasa Indonesia. Citra Umbara.

Moh Roqib. (2009). Ilmu Pendidikan Islam. PT. LKS Printing Cemerlang.
Mudjito. (2007). Pedoman Pelaksanaan Pendidikan Berorientasi Kecakapan Hidup Taman KanakKanak. Departemen Pendidikan Nasional.

Muhammad Zein. (1995). Methodologi Pengajaran Agama. AK Group.

Muhibbin Syah. (2000). Psikologip Pendidikan. Remaja Rosda Karya.

Mukhlish. (2019). PENDIDIK DALAM PERSPEKTIF HADITS RASULULLAH SAW. Jurnal Sains Riset, 9(April), 82-85.

Nata, A. (2009). Perspektif Islam Tentang Strategi Pembelajaran. Kencana Prenada Media Group.

Neong Muhadjir. (1996). Metode Penelitian Kualitatif. Grasindo.

Ngalimun. (2016). Strategi Dan Model Pembelajaran. Aswaja Pressindo.

Ramayulis. (1994). Ilmu Pendidikan Islam. Kalam Mulia.

Saefuddin Azwar. (1998). No Title. Pustaka Pelajar.

Suharsimi Arikunto. (1998). Prosedur Penelitian, Suatu Pendekatan Praktek. PT Rineka Cipta.

Sukardi, \& Sugiyanti. (2013). Pendidikan Karakter Dalam Pembelajaran Di Sekolah Dasar Berbasis Kurikulum 2013. Seminar Nasional Dan Bedah Buku Pendidikan Karakter Dalam 
Implementasi Kurikulum 2013, 146-158.

Sutrisno Hadi. (2004). Metodoloigi Research I. Andi Offset.

Yulianingsih, W., Suhanadji, S., Nugroho, R., \& Mustakim, M. (2020). Keterlibatan Orangtua dalam Pendampingan Belajar Anak selama Masa Pandemi Covid-19. Jurnal Obsesi : Jurnal Pendidikan Anak Usia Dini, 5(2), 1138-1150. https://doi.org/10.31004/obsesi.v5i 2.740

Zakiah Darajat. (2005). Ilmu Jiwa Agama. P.T. Bulan Bintang.

Zakiah Derajat. (1993). Ilmu Jiwa Agama. Bulan Bintang. 